\title{
Sagledavanje posledica krize izazvane pandemijom COVID-19 na održivost preduzeća
}

\section{Consideration of the consequences of the crisis caused by the COVID-19 pandemic on the sustainability of enterprises}

\author{
Jovana Radoičić ${ }^{1 *}$, Ljiljana Arsić ${ }^{2}$ \\ 1,2,Univerzitet u Prištini sa privremenim sedištem u Kosovskoj Mitrovici, Ekonomski fakultet, Kolašinska \\ 156, 38220 Kosovska Mitrovica / University of Priština (temporary in Kosovska Mitrovica), Faculty of \\ Economics, Kolašinska 156, 38220 Kosovska Mitrovica
}

*Autor za prepisku / Corresponding author

Rad primljen / Received: 10.04.2021, Rad prihvaćen / Accepted: 20.05.2021.

\begin{abstract}
Sažetak: Uzročnik tekuće krize je specifičan, neekonomski faktor i zato je veoma teško povlačiti paralele sa onima iz bliske prošlosti i njihovim efektima na tržište rada. Pandemija COVID-19 ozbiljno je uzdrmala srpsku ekonomiju i dovela u pitanje održivost velikog broja preduzeća i radnih mesta. Povećanje stope nezaposlenosti specifičnost je svake krize. Međutim, ova je po mnogo čemu atipična. Zato fokus svih budućih strategija, politika i mera mora biti ekonomski oporavak i izgradnja stabilne i na krize fleksibilne ekonomije. Izbijanje i neverovatno brzo širenje bolesti prouzrokovalo je zatvaranje gradova, čak i nacionalnih ekonomija, što se negativno odrazilo na ekonomski prosperitet i zaposlenost. Cilj rada je analiza uticaja pandemije COVID-19 na ekonomski razvoj, stabilnost i (ne)zaposlenost u svetu i u Republici Srbiji. Istraživanje je izvršeno na osnovu uporedne analize vrednosti pojedinih indikatora ekonomskog razvoja u periodu pre i posle pojave pandemije COVID-19. Podaci su prikupljeni metodom anketiranja sprovedenom u preduzećima, a takođe putem polustrukturisanih intervju s ključnim sagovornicima, kao i na podacima Republičkog zavoda za statistiku (RZS). Autori ukazuju na to koje su posledice uticaja pandemije COVID-19 na indikatore ekonomskog razvoja i indikatore zaposlenosti i predlažu mere koje je neophodno preduzeti u cilju prevazilaženja negativnih posledica krize.
\end{abstract}

Ključne reči: COVID-19, zaposlenost, ekonomski razvoj, održivost, otpornost privrede, kriza.

\begin{abstract}
The cause of the current crisis is a specific, non-economic factor and that is why it is very difficult to draw parallels with those from the recent past and their effects on the labor market. The pandemic caused by the COVID19 has seriously shaken the Serbian economy and called into question the sustainability of a large number of companies and jobs. Increasing the unemployment rate is a specific feature of any crisis. However, this is atypical in many ways. Therefore, the focus of all future strategies, policies and measures must be economic recovery and building a stable and crisis-flexible economy. Outbreaks and incredibly rapid spread of the disease have caused the closure of cities, even national economies, which has had a negative impact on economic prosperity and employment. The aim of this paper is to analyze the impact of the COVID-19 on economic development, stability and (un)employment in the world and in the Republic of Serbia. The research was conducted on the basis of a comparative analysis of the values of individual indicators of economic development in the period before and after the pandemic COVID-19 on data collected through surveys in companies, semi-structured interviews with key interlocutors and the Republic Bureau of Statistics. The authors point out the consequences of the pandemic impact on indicators of economic development and employment indicators and suggest measures that need to be taken in order to overcome the negative consequences of the crisis.
\end{abstract}

Keywords: COVID-19, employment, economic development, sustainability, economic resilience, crisis.

${ }^{1}$ orcid.org/0000-0002-3681-3877, e-mail: jovanaradoicic91@gmail.com

${ }^{2}$ orcid.org/0000-0002-3582-8161, e-mail: Ijiljana.arsic@pr.ac.rs 


\section{UVOD / INTRODUCTION}

Decembra 2019. godine se pojavljuje, Corona virus SARS 2. Prvi slučaj je zabeležen u kineskom gradu Vuhan, odakle se širi neverovatnom brzinom preko cele Evrope i ostatka sveta. Od tada pa sve do danas situacija sa virusom se ne poboljšava, sve je više smrtnih slučajeva, ekonomija čitavog sveta se destabilizuje svakim danom sve više. Na osnovu informacija dostupnih na sajtu Svetske zdravstvene organizacije (WHO, 2021), broj potvrđenih Covid-19 slučajeva 07. marta 2021. godine je 115.967.664, a broj preminulih iznosi 2.579.775.

Pored toga što je ovaj virus uzrok najveće smrtnosti stanovništva posle Drugog Svetskog rata, ekonomske posledice njegove pojave i širenja su nesagledive. Kriza izazvana pandemijom Covid-19 je jedna od najvećih kriza civilizacije, po obimu i vremenu trajanja. Pandemija utiče na društveni, socijalni i ekonomski aspekti života.

Iznenadni ekonomski poremećaj izazvan širenjem epidemije Covid-19 nije samo destruktivan već ima i propratne implikacije jer je stvorio šokove potražnje i ponude u gotovo svim oblastima ljudskih aktivnosti (El-Erian, 2020). Negativan ekonomski uticaj pandemije COVID-19 je evidentan u svim segmentima industrije. Pandemija je izazvala zatvaranje mnogih fabrika, prestanak proizvodnje, otpuštanje radnika, smanjenje kupovne moći i standarda svetske populacije. Zdravstvena kriza je izazavala pravu ekonomsku krizu. Pre svega, zbog socijalnog distanciranja se gase pojedina tržišta, otkazuju se poslovni događaji i sastanci. Usled neverovatne brzine širenja virusa, potrošači i partneri biraju sigurne luke za svoja ulaganja, uz minimalnu spremnost na rizik.

\section{MATERIJALI I METODE / MATERIALS AND METHODS}

Prvi deo rada pod nazivom „Uticaj pandemije na svetske ekonomske aktivnosti" se odnosi na analizu uticaja pandemije na globalnu ekonomiju. U ovom poglavlju je predstavljeno trenutno stanje širenja oboljenja COVID-19 u svetu, po regionima. Zatim je ukazano na stanje na tržištu rada i na kretanje svetskog BDP-a. Drugi deo pod nazivom „Uticaj pandemije na srpsku ekonomiju" ukazuje na trenutno stanje srpske ekonomije, prema indikatorima ekonomskog razvoja zemlje i pada zaposlenosti, kao i procenu mogućnosti njenog daljeg razvoja i buđenja iz recesije.

U ovom radu je korišćeno više izvora. Naime, pored relevantnih naučnih publikacija, korišćeni su rezultati istraživanja Svetske zdravstene organizacije, Ujedinjenih nacija, OECD-a, Svetske banke i Republičkog zavoda za statistiku. Istraživanje uticaja krize izazvane pandemijom Covid-19 vrši se primenom nekoliko naučnih metoda: deskripcije, komparativne analize, indukcije, dedukcije i metoda anketiranja.

Osnova istraživanja je prikupljanje podataka na osnovu upitnika. Istraživanje je izvršeno na teritoriji Republike Srbije, u periodu od 20.03.2021. do 01.04.2021. godine. Upitinici su poslati elektronskim putem nasumično odabranim ispitanicima, koji su bili u radnom odnosu u proteklih godinu dana. Istraživanjem je obuhvaćeno 100 ispitanika, od 23 do 56 godina starosti. Pitanja se odnose na to kakav uticaj je imala kriza izazvana pandemijom na njihova radna mesta, obaveze i primanja.

Nakon prikupljanja podataka, izvršena je njihova statistička obrada pomoću statističkog softverskog paketa The Statistical Package for the Social Sciences - SPSS.

Autori su postavili sledeće hipoteze:

H1: Došlo je do uvećanja stope nezaposlenosti u svetu i Republici Srbiji, pod uticajem pandemije Covid-19;

H2: Veliki broj preduzeća koja pos/uju na teritoriji Republike Srbije je ugašeno ili rade manjim obimom i profitima, kao posledica krize izazvane pandemijom.

\section{REZULTATI I DISKUSIJA / RESULTS AND DISCUSSION}

Uticaj pandemije na svetske ekonomske aktivnosti / The impact of the pandemic on world economic activities

Zbog visokog nivoa globalizacije, velikog protoka stanovništva u svetu i velike reproduktivne stope širenja virusa, pandemija Covid-19 je iznenada pogodila mnogo zemalja, zarazivši stotine hiljada ljudi i ubivši desetine hiljada u najbržoj krizi bez presedana ikada zabeleženoj, što je takođe dovelo do ozbiljne ekonomske krize u istoriji (Berchin, Baltazar, 2020). Podaci o brzini širenja Covid-19 i pojave novih slučajeva po regionima sveta su dostupni na sajtu Svetske zdravstvene organizacije (WHO, 2021). Iz tabele 1 se vidi da je do 07. marta 2021, kada je pristupljeno navedenim podacima, najveći broj zaraženih zabeležen u Americi, a najmanji broj potvrđenih slučajeva u regionu Zapadnog Pacifika. Broj smrti izazavanih ovim virusom je takođe najveći u Americi, a najniža stopa smrtnosti je zabeležena na Zapadnom Pacifiku. Po oba ova kriterijuma, Evropa je na drugom mestu.

Uticaj bolesti na društvo i ekonomiju može se videti iz zatvaranja gradova širom sveta, ograničenja mobilnosti radne snage, zabrana putovanja, suspenzija vazdušnog saobraćaja i najvažnije usporavanja ekonomije (WHO, 2021). Pandemija COVID-19 je dovela do zatvaranja mnogih fabrika, do pojave nezaposlenosti i smanjenja kupovne moći i pada životnog standarda. 
Tabela 1 - Covid-19 situacija po regionima

Table 1 - Covid-19 situation by regions

\begin{tabular}{|l|c|c|}
\hline Region & $\begin{array}{c}\text { Broj } \\
\text { zaraženih }\end{array}$ & $\begin{array}{c}\text { Broj } \\
\text { preminulih }\end{array}$ \\
\hline Amerika & 51.531 .438 & 1.237 .781 \\
\hline Evropa & 39.586 .056 & 881.642 \\
\hline $\begin{array}{l}\text { Jugoistočna } \\
\text { Azija }\end{array}$ & 13.684 .394 & 210.214 \\
\hline $\begin{array}{l}\text { Istočni } \\
\text { Mediteran }\end{array}$ & 6.616 .840 & 147.284 \\
\hline Afrika & 2.886 .005 & 73.204 \\
\hline $\begin{array}{l}\text { Zapadni } \\
\text { Pacifik }\end{array}$ & 1.662 .186 & 29.637 \\
\hline
\end{tabular}

Izvor / Source: WHO (2021)

Kako se navodi u publikaciji (United Nations, 2021), u 2020. godini svetska proizvodnja opala je za 4,3 odsto, tri puta više nego tokom globalne finansijske krize, koja se odigrala 2009. Predviđa se oporavak u 2021. godini od 4,7 procenata. Međutim, taj rast će jedva nadoknaditi gubitke nastale u 2020. godini u slabo razvijenim ekonomijama, sa procenjenim padom proizvodnje od 5,6 procenata u 2020 . godini, zbog strogih i produženih mera zaključavanja koje su uvedene u mnogim evropskim zemljama i nekim delovima Sjedinjenih Država. Kontrakcija je bila relativno blaža u zemljama u razvoju, s tim da se proizvodnja smanjila za 2,5 procenta u 2020 . godini.

Pored toga, $u$ istoj publikaciji Ujedinjenih nacija se navodi da je pandemija pokrenula ozbiljnu krizu zapošljavanja širom sveta. Do aprila 2020. godine mere punog ili delimičnog zaključavanja pogodile su skoro 2,7 milijardi radnika, što predstavlja oko 81 procenat globalne radne snage. Uprkos određenom poboljšanju kasnije tokom godine, stope nezaposlenosti u većini zemalja i dalje ostaju znatno iznad nivoa pre krize. Gubitak posla i dohotka doveo je oko 131 milion ljudi u siromaštvo 2020. godine, od kojih su mnogi žene, deca i ljudi iz marginalizovanih zajednica. Ženska populacija je posebno pogođena pandemijom, jer one čine više od 50 procenata radne snage u radno intenzivnim uslužnim sektorima, poput trgovine na malo, ugostiteljstva i turizma, gde rad na daljinu često nije opcija. Grafikonom 1. je predstavljena promena stope nezaposlenosti 2020. godine u odnosu na 2019. u SAD, Evropskoj Uniji, Japanu, Brazilu i Filipinima. Evidentan je negativan uticaj COVID-19 na stopu nezaposlenosti u posmatranim zemljama.

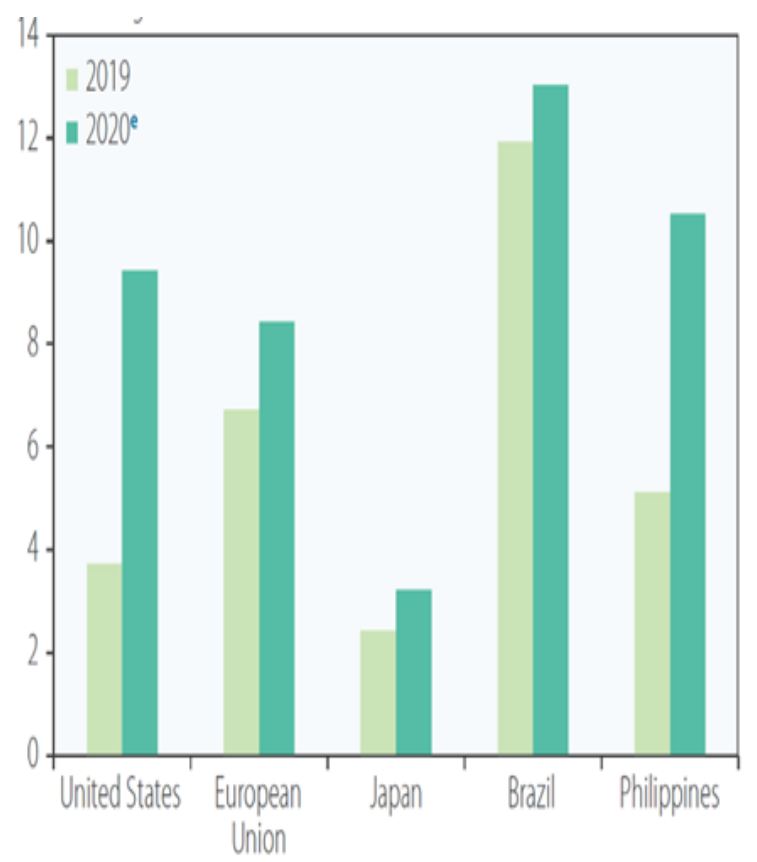

Grafikon 1 - Stopa nezaposlenosti (2019-2020)

Graph 1 - Unemployment rate (2019-2020) Izvor / Source: United Nations (2021)

Pandemijom su najviše pogođena mikro, mala i srednja preduzeća. Ove firme su veoma zavisne od svojih rutinskih poslovnih transakcija i malog broja kupaca (Shafi i dr., 2020). One su najveće žrtve ove pandemije, jer u poređenju s velikim preduzećima, obično nemaju dovoljno resursa, posebno finansijskih i upravljačkih, i nisu pripremljeni za takve poremećaje koji će verovatno trajati duže nego što se očekivalo (Williams, Schaefer, 2013; Bartik i dr., 2020).

Međutim, pojavom vakcine protiv Covid-19 izgledi su se poboljšali. Naime, na osnovu izveštaja OECD Economic Outlook (2021) prognozira se da će globalni rast BDP-a ove godine biti $5,6 \%$ i da će globalna proizvodnje biti na nivou na kom je bila pre pandemije. Brzina vakcinacije će biti presudna za vraćanje globalne privrede u normalu. Ekonomski razvoj je intervencija državne politike čiji je cilj poboljšanje blagostanja ljudi, a ekonomski rast je fenomen tržišne produktivnosti i povećanja BDP-a (Ahadu, 2020). Realni BDP je tržišna vrednost roba i usluga koje privreda proizvodi tokom vremena (Sirah, Atilaw, 2020). Obično se meri procentualnom stopom povećanja realnog bruto domaćeg proizvoda (Dilek, 2016; Doğan, 2012). Na Grafikonu 2. je predstavljen rast BDP-a na svetskom nivou od 2015. do 2020 , uz projekcije za period do 2025 . godine. 


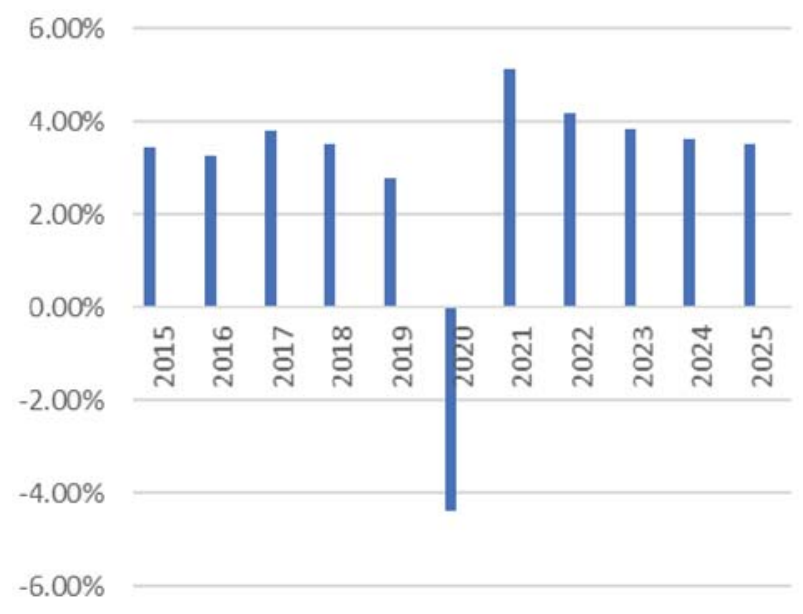

Grafikon 2 - Rast globalnog BDP-a (2015-2025)

Graph 2 - Global GDP growth (2015-2025)

Izvor: prilagođeno prema: Statista (2021)

Source: adapted to: Statista (2021)

Uticaj pandemije na srpsku ekonomiju /

The impact of the pandemic on the Serbian economy

Prvi registrovani slučaj Covid-19 u Srbiji zabeležen je u Subotici 06.03.2020.godine. Do 24.03. 2021. godine je ukupan broj zaraženih od pojave pandemije dostigao 566.669 uz 0,89\% smrtnosti. Republika Srbija je u prvom mesecu pojave epidemije proglasila vanredno stanje, primenila je restriktivni model koji je obuhvatao određene mere poput zatvaranja granica, zatvaranja gradova, ograničenja kretanja uz uvođenje policijskog časa i višednevnih zatvaranja. Mere su obuhvatale i obustavu rada svih prodavnica osim prehrambenih, premeštanje posla iz kancelarija u domove zaposlenih osim u slučajevima kada to nije moguće ili je neophodno obezbediti osnovna dežurstva, zatvaranje ustanova obrazovanja na svim nivoima, ukidanje javnih i socijalnih usluga u direktnom kontaktu sa građanima i dr. (UN Women, 2020).

Srpska ekonomija je teško pogođena pandemijom. Kriza je izazvala veliko smanjenje bruto domaćeg proizvoda (BDP) u poređenju s istim periodom prethodne godine po stopi od $6,4 \%$ u drugom kvartalu 2020, na njenom vrhuncu (UNDP Serbia, 2020). Kriza izazvana pandemijom je negativno uticala na svakog aktera u privredi, a njen uticaj na radnike je bio različit u zavisnosti od veličine preduzeća i sektora kojem preduzeće pripada. Tako su najviše bili pogođeni radnici zaposleni u manjim preduzećima i u onim sektorima koji su direktno ograničeni zabranom kretanja, kao i zaposleni u neformalnoj privredi (UNDP Serbia, 2020). Više od dve trećine malih i srednjih preduzeća prekinulo je poslovanje zbog Covid-19 (CEVES, 2020). Na osnovu iste publikacije iz 2020. godine se može zaključiti da su preduzeća srednje veličine koja posluju na teritoriji Republike Srbije najbolje odgovorila na krizu koja je izazvana pandemijom. Naime, ona su bila dovoljno fleksibilna, što je karakteristika malih preduzeća, i prilagodila su se novonastalim okolnostima. $S$ druge strane, imaju resurse i kapacitete približno kapacitetima i resursima velikih preduzeća, što im je pomoglo da nabave finansijska sredstva iz više izvora. Velika preduzeća su imala kapacitete, strukturu i resurse, ali su pretrpela posledice zbog toga što su bila kruta i spora i nisu bila u stanju da se tako brzo prilagode okruženju koje se brzo menjalo na početku krize (CEVES, 2020). Iz tog razloga su se veće kompanije koje posluju u Republici Srbiji pre odlučivale na finansijske izvore u vidu zaduživanja (Grafikon 3).

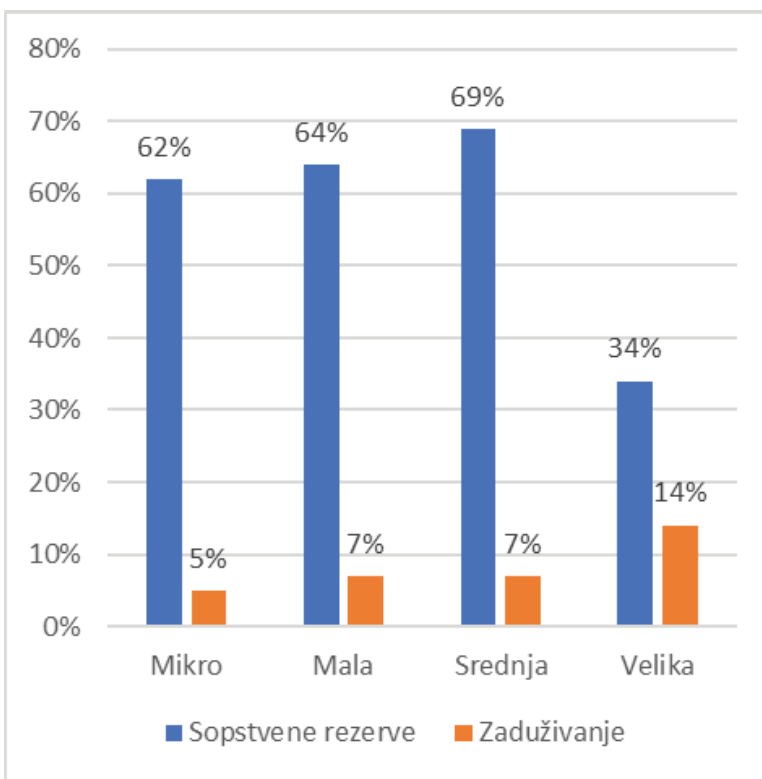

Grafikon 3 - Izvori sredstava kompanija u doba pandemije $u R S$

Graph 3 - Sources of funds of companies during the pandemic in the Republic of Serbia Izvor: prilagođeno prema: (CEVES, 2020)

Source: adapted to: (CEVES, 2020)

Suzbijanje pandemije COVID-19 zahteva efikasno državno upravljanje, a odgovori otkrivaju mnogo toga o prioritetima, snagama i slabostima nacionalnog sistema upravljanja (Wallis, Zhuo, 2020). Republika Srbija je efikasno odgovorila na promene izazvane pandemijom, kroz svoje programe podrške. Naime, država je odvojila najveći procenat od BDPa u odnosu na druge zemlje u regionu kako bi realizovala ovaj program podrške (Tabela 2). Mere su uvedene kako bi se ublažili efekti smanjene potražnje na rad preduzeća i dohotke radnika. 
Tabela 2 - Mere budžetske podrške koje su donele zemlje Zapadnog Balkana, milijarde $€$

Table 2 - Budget support measures that are brought by the countries of the Western Balkans, billions of $€$

\begin{tabular}{|c|c|c|}
\hline & Ukupno & $\%$ BDP \\
\hline Albanija & 0,4 & 2,4 \\
\hline BiH & 0,4 & 2,3 \\
\hline Crna Gora & 0,05 & 1,0 \\
\hline Severna Makedonija & 0,2 & 2,0 \\
\hline Srbija & 3,2 & 6,7 \\
\hline
\end{tabular}

Source: adapted to: (World Bank Group, 2020)

U Srbiji je tokom 2020. godine izgubljeno ukupno 94.100 radnih mesta, a zabeleženo je smanjenje prosečnog stvarnog radnog vremena tokom nedelje od $7,5 \%$ tokom drugog kvartala 2020 , u poređenju sa nivoima iz istog perioda prethodne godine (RZS, 2020).

$\mathrm{Na}$ osnovu izveštaja Republičkog zavoda za statistiku (RZS) o kretanju na tržištu rada u četvrtom kvartalu 2020.godine, stope nezaposlenosti su porasle u odnosu na treći kvartal prošle godine. Naime, kod stanovništva starog 15 i više godina došlo je do smanjenja zaposlenosti (-15.700) i gubitka radnih mesta (-20.900), dok je nezaposlenost povećana (+29.000), na međukvartalnom nivou, stope zaposlenosti i neaktivnosti smanjene su i dostigle nivo od $49,7 \%$, odnosno $44,9 \%$ u četvrtom kvartalu 2020. Istovremeno, stopa nezaposlenosti porasla je za $0,9 \%$ i dostigla je nivo od $9,9 \%$ (RZS, 2020). Pored toga, u uslovima krize radnici su bili primorani da menjaju svoje navike na poslu, postali su fleksibilni i prilagođavali se novonastalim okolnostima.

Kako bi se videlo na koji način je kriza uticala na radnike i njihova radna mesta, autori su sproveli istraživanje koje je obuhvatalo 100 zaposlenih lica sa teritorije RS, a koji su bili u radnom odnosu od početka pandemije. Naime, većina ispitanika radi u privatnom sektoru $(75 \%)$, dok ostali pripadaju javnom sektoru. S obzirom na činjenicu da su za vreme pandemije mnoga preduzeća privremeno obustavila svoje poslovanje, $28 \%$ ispitanih radnika je bilo primorano da obustavi i svoj rad. To se, pre svega, odnosi na radnike u oblasti ugostiteljstva. Kod 16\% ispitanika privatnog sektora se ništa nije promenilo, radili su kao i do pojave pandemije. Zatim, 31\% anketiranih radnika iz istog sektora je navelo da im je za vreme pandemije smanjena plata. Ispitanici koji rade u javnom sektoru su naglasili da su uglavnom radili od kuće (16\%), a ostalih $9 \%$ je radilo uz korigovanje smena - smanjen je broj smena ili je skraćeno radno vreme. Najvećem procentu ispitanih radnika je, pod uticajem pandemije, smanjena plata (31\%) i $28 \%$ njih je moralo da obustavi svoj rad. Rezultati istraživanja su predstavljeni Grafikonom 4.
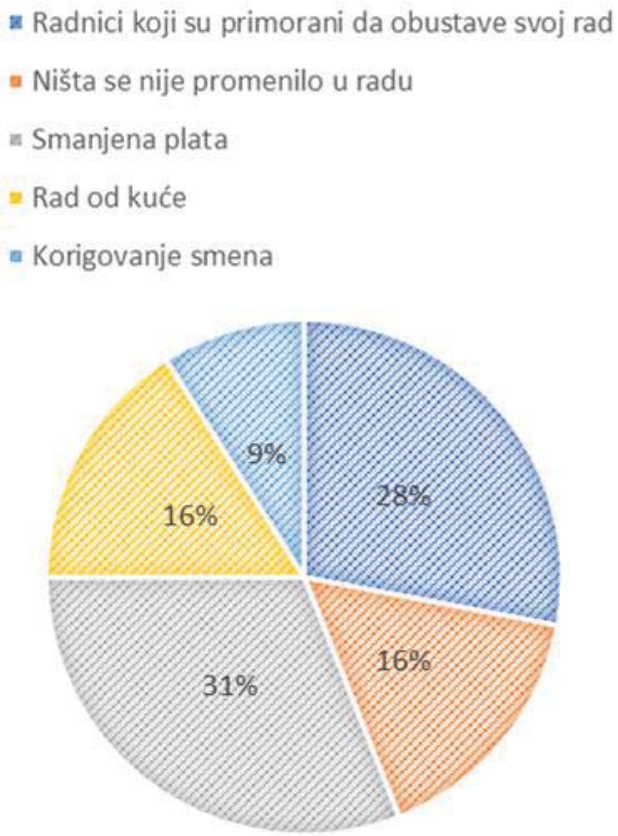

Grafikon 4 - Uticaj pandemije na radnike u RS Graph 4 - Impact of the pandemic on workers in the Republic of Serbia Izvor: kalkulacija autora Source: author's calculation

Prioritet ekonomija pogođenih pandemijom Covid-19 trebalo bi da bude ulaganje u zelenu privredu i zelena radna mesta. Menadžment životne sredine (ekološki menadžment) predstavlja novi koncept za rešavanje ekoloških problema (Vujović i dr, 2020). Zelena ekonomija je novi ekonomski oblik koji je tržišno orijentisan, zasnovan na tradicionalnoj industrijskoj ekonomiji i razvijen je u cilju ekonomske i ekološke harmonije (Radoičić, Arsić, 2020). Zeleno preduzetništvo podrazumeva način u kom je novac moguće napraviti u saradnji sa ekologijom i idejom zaštite životne sredine, što znači da ekonomija i ekologija nisu prirodni neprijatelji (Arsić i dr, 2020). Razvoj zelene privrede povlači za sobom razvoj cirkularne ekonomije, koja je u Republici Srbiji na početku razvoja, a koja ima brojne pogodnosti. Primena cirkularne ekonomije u praksi donosi niz benefita na nacionalnom nivou u domenu efikasnije eksploatacije resursa (ovim se smanjuju ukupni troškovi i uvozna zavisnost zemlje); životne sredine (smanjuju se pogubni efekti narušavanja životne sredine), ekonomije (stvaraju se nove mogućnosti kreiranja dodate vrednosti) i socijalnih aspekata (kreiraju se nova radna mesta, uvode se održivi oblici ponašanja potrošača) (Brnjas i dr, 2016). 


\section{ZAKLJUČAK / CONCLUSION}

Da bi se uspešno odgovorilo na krizu, u privredi mora da postoji efikasna saradnja između institucija, države i organizacija. Pandemija Covid-19, kao ne samo zdravstvena i humanitarna kriza, već i kao ekonomska, je uslovio preduzeća da postanu fleksibilnija nego ikad ranije. Naša nova realnost je puna neizvesnosti i rizika i zato se kompanije, da bi opstale i napredovale, moraju prilagođavati i brzo reagovati. Sprovedenim istraživanjem u ovom radu i korišćenjem podataka iz relevantnih publikacija, postavljene hipoteze: „Došlo je do uvećanja stope nezaposlenosti u svetu i Republici Srbiji, pod uticajem pandemije izazvane pandemijom Covid-19. Veliki broj preduzeća koja posluju na teritoriji Republike Srbije je ugašeno ili rade manjim obimom i profitima, kao posledica krize izazvane pandemijom"su potvrđene.

Pored toga što je kriza izazvana pandemijom dovela do velikih negativnih efekata, Republika Srbija, kao i sve ostale pogođene ekonomije u narednom vremenskom periodu mogle bi da usmere svoje investicije u zelenu privredu. $\mathrm{Na}$ taj način bi pospešili razvoj privrede i povećali njenu aktivnost, kao i stopu zaposlenosti.

\section{LITERATURA / REFERENCES}

[1] Ahadu, E. (2020). Novel Corona Virus COVID-19: Impact of Economic Development and Mitigating Solution for Developing countries, Journal of Humanities and Social Sciences, 8(3), 86-91, DOI: 10.11648/j.hss.20200803.11

[2] Arsić, Lj., Premović, J., Milićević, Z., Đokić, N., Stošić, N. (2020). Afirmacija modela cirkularne ekonomije u malim i srednjim preduzećima, Ecologica, 27(100), 647-654.

[3] Bartik, M., Bertrand, Z.B., Cullen, E.L. Glaeser, Luca, M., Stanton, C. (2020). How are small businesses adjusting to COVID-19? Early evidence from a survey Harvard Business School Working Paper, Vol. 20, No. 102, pp. 1-37.

[4] Berchin, I., Baltazar, J. (2020). GAIA 3.0: Effects of the Coronavirus Disease 2019 (COVID-19) outbreak on sustainable development and future perspectives, Research in Globalization, Vol. 2, 100014

[5] Brnjas, Z., Drašković, B., Grbić, V. (2016). Cirkularna ekonomija: Savremeni koncept efikasne i održive ekonomije. Ecologica, 23(84), 685-689.

[6] CEVES (2020). Covid kriza i srpska MSP: Procena uticaja i pregled budućih scenarija.

Dostupno na: https://ceves.org.rs/the-covid-crisisand-serbias-smes-assessment-of-impact-andoutline-of-future-scenarios/?lang=SR (7.3.2021)
[7] Dilek, S. (2016). Determinants of Unemployment: Empirical Analysis for China. The Journal of Academic Social Science, 50-58.

[8] Doğan, T. T. (2012). Macroeconomic Variables and Unemployment: The Case of Turkey. International Journal of Economics and Financial Issues, 2(1), 71-78.

[9] El-Erian, M. (2020). The Coming Coronavirus Recession and the Uncharted Territory Beyond. Foreign Affairs, Media Report. Dostupno na: https://www.foreignaffairs.com/articles/2020-0317/coming-coronavirus-recession (07.03.2021)

[10] OECD Economic Outlook (2021), privremeni izveštaj mart 2021.

[11] Prasad, S., H.-C. Su, Altay, N., Tata, J. (2015). Building disaster-resilient micro enterprises in the developing world, Disasters, 39(3), 447-466.

[12] Radoičić, J., Arsić, Lj. (2020). Cirkulana ekonomija putokaz ka zelenim radnim mestima, Ecologica, 27(98), 332-338.

[13] Republički zavod za statistiku, RZS (2020). Anketa o radnoj snazi - Kretanja na tržištu rada u četvrtom kvartalu 2020.

[14] Shafi, M., Liu, J., Ren, W. (2020). Impact of COVID-19 pandemic on micro, small, and medium-sized Enterprises operating in Pakistan, Research in Globalization, 2, 100018.

[15] Sirah, E., Atilaw, W. (2020). Effect of Covid-19 Pandemic on Unemployment Rate and Economic Growth: The Case of Ethiopia, Research on Humanities and Social Sciences, 10(13), DOI: 10.7176/RHSS/10-13-02

[16] Statista (2021). https://www.statista.com/statistics/273951/growt h-of-the-global-gross-domestic-product-gdp/ (Posećen 07.03.2021)

[17] UNDP Serbia (2020). COVID-19, procena socioekonomskog uticaja u Republici Srbiji. Dostupno na: https://www.rs.undp.org/content/serbia/sr/ home/library/crisis_prevention_and_recovery/co vid-19-socio-economic-impact-assessment-.html (Posećen 07.03.2021)

[18] United Nations (2021), World Economic Situation And Prospects: February 2021 Briefing, No. 146, Dostupno na:

https://www.un.org/development/desa/dpad/publi cation/world-economic-situation-and-prospectsfebruary-2021-briefing-no-146/ (07.03.2021)

[19] UN Women (2020). Uticaj COVID-19 pandemije i mera za njeno sprečavanje na zaposlenost $i$ uslove rada žena i muškaraca u Srbiji. Dostupno na: https://www.secons.net/files/publications/113publication.pdf (Posećen 07.03.2021) 
[20] Vujović, S., Premović, J., Arsić, Lj. (2020), Ekološki aspekti materijalne osnove ruralnog turizma, Ecologica, 27(97), 65-69.

[21] Wallis, V., Zhuo, M. (2020). Socialism, capitalism, and the COVID-19 epidemic: Interview with Victor Wallis, International Critical Thought, 10(2), 153160.

doi.org/10.1080/21598282.2020.178392010.108 0/21598282.2020.1783920

[22] WHO (2021), WHO Coronavirus (COVID-19) Dashboard. Dostupno na:

https://covid19.who.int/ (Posećen 07.03.2021)
[23] Williams, S., Schaefer, A. (2013). Small and medium-sized enterprises and sustainability: Managers' values and engagement with environmental and climate change issues, Business Strategy and the Environment, 22(3) 173-186.

[24] World Bank Group (2020). Ekonomski i socijalni uticaj COVID-19, izgled za zapadni Balkan. Dostupno na https://thedocs.worldbank.org/ en/doc/486361588146392647-0080022020/ original/WBRER17TheEconomicandSociallmpac tofCOVID19OutlookHardTimesRequireGoodEco nomicsBosnian.pdf. (Posećen 07.03.2021) 